\title{
The Impact of the Lebanese Civil War on Weaving the Texture of the Narrative of Ghada Al-Samman's Beirut Nightmares
}

Nedal Al-Mousa

Arab Open University (AOU), Jordan Branch

\begin{abstract}
The paper is concerned with examining the impact of the Lebanese civil war on weaving the fabric of the narrative of Ghada al-Samman's novel Beirut Nightmares (1975). The enormous atrocities and people's great sufferings brought about by the civil war are filtered through the consciousness of a femrale narrator. The narrator's self-imposed mission to bear witness to the devastating effect of the civil war on a people and their country is presented in part in diary-like accounts of events. For al-Samman, factual representation of the events of the civil war deemed to be inadequate to portray their tremendous traumatic effect expressed in peoples' overwhelming sense of dislocation, painful recognition of the superficiality of human ties, and the unmasking of the dark side of human soul. The civil war, I argue, serves as a remarkable fertile ground for invigorating al-Samman's literary imagination as is well reflected in her employment of a wide range of modes of representation and discourses, including diary-like account of events, fantasy, nightmares, dreams, surrealistic elements, anthropomorphism, and anthropocentrism. That is to the end of portraying the impact of the civil war on the private lives of the individuals in the most effective dramatic manner. This polyphonic strategy, in the terminology of Michail Bachtin, enables alSamman to rigorously probe the social, political, moral, and psychological effects of the civil war on the micro and the macro levels.

Key words: anthropocentrism, anthropomorphism, fantasy, imagination, multiple discourses, texture

Cite as: Al-Mousa, N. (2020). The Impact of the Lebanese Civil War on Weaving the Texture of the Narrative of Ghada Al-Samman's Beirut Nightmares. Arab World English Journal for Translation \& Literary Studies 4 (4) 202-212.

DOI: http://dx.doi.org/10.24093/awejtls/vol4no4.17
\end{abstract}


Because war puts the greatest pressure on human nature, relationships, and institutions, it also becomes a fertile ground for the literary imagination. Thus, the Trojan War, the Thirty Years War, the Spanish Civil War, the American Civil War, the Mau-Mau War, etc. Each has generated a distinctive body of literature appropriate to its time, place, and sociohistorical circumstances. Therefore, Nigerian Civil War literature belongs to a global tradition of war literature. But it displays peculiar thematic and stylistic features that reveal not only the specificity of the Nigerian experience but also the more human aspects of that dark chapter in Nigerian history, which ordinary historical accounts are not equipped to reveal. ( Amuta 1988, p. 86)

The Lebanese civil war can be added to the list of civil wars referred to in the epigraph. Affirming the insights set out in the epigraph, the Lebanese civil war which broke out in (1976) and lasted for fifteen years, serves as a remarkable 'fertile ground' for energizing Ghada alSamman's literary imagination whereby she can produce civil war literature marked with distinctive thematic and stylistic features. Al-Samman's highly imaginative artistic representation of the Lebanese civil war is well reflected in her employment of diverse modes of expression and multiple discourses, particularly in Beirut Nightmares (1975) (the second volume of a trilogy dealing with Lebanon's civil war, preceded by Beirut 75 (1995) and followed by Night of the Trillion Beirut (2014)) to portray the devastating impact of the civil war on a people and their country. Beirut Nightmares is a personal account and reflection on the events of Lebanon's civil war. It consists of a series of nightmares, each of which forms a sort of mini-chapter. It is in part a diary-like account of events in the life of the narrator over a two-week period of time during which she is trapped in her house after street battles and sniper fire have turned her neighborhood into a virtual prison. The narrator's suffering from an overwhelming sense of dislocation brought about by her traumatic recognition of the superficiality of social ties, the dark side of the human soul, and her disenchantment with previously held social values and priorities figure as pivotal issues throughout Beirut Nightmares. These traumatic consequences are encapsulated in Nightmare ( 80):

After eight months of civil war, you become conscious of how the frightful chaos around you has taken possession of your inner being, and you feel the need to reorder the world inside you, including your values and your ways of understanding things. Everything looks different in the light of the surprises that have come your way, and the discoveries which, whether they've come as painful blows or sources of intense joy, have in either case left you both baffled and astounded (p.80).

To emphasize further this state of affairs, later on in Nightmare (50 )she further adds:

Arab World English Journal for Translation \& Literary Studies 
You find yourself re-examining everything, and the place it's occupied in your life: your friends, your work, your place of residence, your heart and your spirit's ability to gauge which direction you're heading in as you speed along in your boat of stone over the vast, dispassionate sea. Down is now up, and up is down. Ceilings have become walls, and walls have become roads leading to who knows where. And you? Just exactly who are you anyway? (Al-Samman 1975,pp.166-167).

For al-Samman, factual representation of the events of the civil war and their impact on the private lives of individuals is deemed to be an inadequate style of writing. Thus she combines the employment of mimetic representation, based on her bearing witness to the events, and the use of a wide range of stylistic and representational devices and discourses, including fantasy, nightmares, dreams, surrealism, anthropomorphism, and anthropocentrism. This narrative strategy employed in the novel chimes with Holger Klein's contention that it is not uncommon that war in literature serves as a tool to produce a wide variety of modes of "articulation": "War in itself is a contingent event, a neutral backcloth, and vehicle, capable of articulation in a wide variety of ways."(qtd.in Cooke 1987, 25). The following extract from Ghada al-Samman's collection of interviews, The Tribe Interrogates The Killed Woman(1981), sheds light on her strategy in weaving the fabric of Beirut Nightmares' narrative :

_ A distinctive feature of your novels and stories is their fusion of documentation, fantasy, and sometimes open realism, especially in Beirut Nightmares. What are the lines which separate or unite these modes of representation in weaving the texture of your work?

_There are art schools that tend to portray one picture of human reality and try to bring it into line with a preconceived context, be it political, ideological, or psychological. All art schools try to enshrine their own modes of representation. In fact, there is no single human reality, each human being has more than one self, and he interacts at all levels in political, metaphysical, psychological, and economic spheres. That is within an intricate network of vast, endless action, reaction, and in-action. Even fantastic reality is not purely fantastic; it is rather part of living reality, dream, nightmare, death, madness, metaphysics, sickness, and isolation. All of these are facets of infinite truth. Thus, for me, the style of novel writing is a means to an end, and content determines form like a river which digs its own course.( Al-Samman 1981,p, 280 ,my translation)

Al-Samman's novel Beirut 75 provides another informative reference to the use of fantasy( the predominant mode of representation in Beirut Nightmares ) in realistic fiction. In the course of his reflections on the fantastic halo, he bestows on his beloved Hameeda, the fisherman Mustafa in this novel remarks: "Fantasy is not necessarily the opposite of reality. It is simply the other face of reality" ( Al-Samman 1995,30). This remark brings to mind Naguib Mahfouz's reflection on the use of fantasy in his fictional writings:

Arab World English Journal for Translation \& Literary Studies 
"The writer may employ fantasy, but he always has an eye to reality. I belong to this type of writer. I may invest my literary works with fantastic dimensions, but this is only to get to the heart of reality" (Faraj 1986,p. 20).

Al- Samman's views also coincide with Kathryn Hume's contention that the representation of reality in literature can be considerably enhanced by the interaction of the "mimetic impulse" and the "fantastic impulse" (Hume 1945, xii ). In her seminal book, Fantasy and Mimesis (1945), Hume points out other primary role of fantasy that is particularly relevant to our study of the process of fantasy in Beirut Nightmares. Fantasy, Hume argues, can enter a work of art as a direct expression of "authorial vision" and a" medium of commentary" upon reality ( Hume 1945,84). It is mainly in these terms, as the ensuing discussion will reveal, that al-Samman extensively uses fantasy as the central discourse in Beirut Nightmares.

Anthropomorphism is the main strategy used by al-Samman to introduce the fantastic plane in the novel, mainly as a means of expressing her personal vision of the civil war and her commentary on its immoral and inhuman dimensions. I am here referring to anthropomorphism in the sense that it includes regular treatment of animals as having human motivations, emotions, language, consciousness, even morality, as is the case throughout Beirut Nightmares. Fables, children's literature, and fairy tales provide classic typical examples of casting animals in the above capacities. According to Bennett and Royle (2009), more subtle anthropomorphism can be found in Herman Melville's Moby Dick, Sylvia Plath's Ariel poems, Derek Walcott's “The Bounty," and Philip Roth's The Human Stain.

In all of these examples of literary works, anthropomorphism figures as a symbolic tool to attack the conceptions of the human. This is the main principle that underlies al-Samman's employment of anthropomorphism in Beirut Nightmares. Nightmare (28) in the novel provides a typical example of al-Samman's peculiar preoccupation with this anthropomorphism of animals, which become identical representatives of the peoples' harsh existence in a civil war. Here is how this Nightmare draws parallels between the moral plight of human beings and the miserable conditions of animals as they try to "cope with" the impact of the civil war which led to their abandonment by the pet shop owner during the civil war:

In the silence, I could hear the sounds being made by the creatures in the pet shop. They'd begun to get hungry and thirsty and were pining away for the sun. Meanwhile, their hopes were fading, and their patience was wearing thin. I heard some of them beating their heads against the sides of their cages in protest, while others sat quietly, awaiting the unfolding of events to come. Some were praying, while others were dreaming or blaspheming or trying to escape or delivering speeches and sermons... just like people...Exactly like us, the residents of this tame, domesticated neighborhood.( Al-Samman 1997, p.41) 
Just as al-Samman's use of what she in Nightmare (77) describes as the properties of nightmares and dreams ( such as "an elevated level of perception" and" a state of heightened alertness") to the end of producing more effective expression of the horrific atrocities of the civil war, she also uses these properties which, it would seem, enable her to hear and grasp the animals' human attributes, such as anxiety, anger, and weariness. In Nightmare (16) she writes:

Their voices seemed laden with fear, anxiety, anger and confusion. Or was I just hearing my own inner voice? .... Or do you suppose it was some sort of mysterious sixth sense on my part that was picking up their vibrations? What was it that had created this bond between us? And why were their voices gradually getting louder and louder until I could hear them enveloping the entire neighborhood coming out of every cage, out of every one of these peaceable, mild tempered creatures wounded by terror, weariness and anticipation?(Al-Samman 1997,p.24)

Attributing human qualities to the animals at the pet shop in Beirut Nightmares is further emphasized in al-Samman's portrayal of their 'sense of shame', 'brokenness and dismay', and 'restless fury 'in Nightmare (51) where she adds:

Meanwhile, all of them without exception were so preoccupied with the trivial biological differences between them that they hadn't stopped to notice the one vital thing they all shared in common, namely, that every one of them was a slave and a prisoner. The fools! Couldn't they see the reality of the situation? On the other hand, perhaps they had seen it. In the eyes of every one of these creatures-the red eyes of the rabbits, the brown eyes of the dogs, the green eyes of the cats and the yellow eyes of the birds- I remembered having detected the very same look. Their varied hues notwithstanding, in all of them there was a teary-eyed gaze filled with shame, brokenness and dismay, as well as a touch of restless fury. ( Al-Samman1997,p.88)

Al-Samman's extensive use of anthropomorphism of animals (as the above quotations reveal) is conceived with a view to juxtaposing animals' human attributes with humans' inhuman lust for blood shed, thirst for revenge, and horrific involvement in acts of mutilation of human bodies by civil war fighters, mutilation which is apparently meant to support forcefully al-Samman's well pronounced anti-anthropocentric stance which has a tremendous impact on weaving the texture of Beirut Nightmares. In Nhightmare (19) the narrator experiences the following nightmarish dream of mutilation:

The fountain was bone dry, without a single drop of water in it. But the armed man twisted the youth's neck until it was up against the fountain's marble rim, then in a flash his knife came down on the major artery in his neck. The youth gasped, and that was that. But the armed man continued to cut into the youth's neck even after his body had fallen limp, while blood came pouring out of the fountain, which may have been dry for years. The blood gushed forth, bursting out in copious torrents ... It flooded the streets, then rose higher and 
higher until it was lapping at people's windows and finally came pouring into the rooms of the houses. It was like some sort of mythical spring that never runs dry. As it rose, it immersed my knees, then my waist, then my chest, then my neck... As I choked on the blood, I began to gasp and scream... then finally I woke up.(Al-Samman1997,pp.28-29)

This horrendous nightmarish description of mutilation in the novel is reminiscent of frequent scenes of brutal mutilation in The IIiad. Having stated that, I should hasten to add that whereas mutilation in the epic can be viewed as indicative of the enormous audacity of great warriors, in Beirut Nightmares al-Samman utilizes mutilation to deal a powerful blow to anthropocentrism . This comes, as it has been previously pointed out, within the framework of al-Samman's conception of her novel as a moral and humanistic critique of that dark chapter of civil war in Lebanon's history.

Anthropomorphism in Beirut Nightmares includes also the use of affective fallacy as is well exemplified in the activities undertaken by the mannequin which steps out of the shop at Hamrah Street, which is located in one of the most prosperous districts of Beirut, to act as a spy in order to thwart the warriors' inhuman practices. She even plays the role of a decoy for catching snipers. Ironically, while the sniper experiences ecstasy as a result of killing innocent people, the mannequin is beside herself with delight on account of saving human lives by helping to kill a sniper:

At that moment she felt a kind of joy she'd never known before. She felt that she'd accomplished something, something different from her work in the display window, and it gave her a sense of inner peace. Even when she discovered that she'd caught fire, she didn't grieve over what had become of her once-spectacular body. Instead, she realized that inside her there was something precious that she'd never been aware of throughout her entire career as a display-window girl. And it was something that couldn't go up in flames. (AlSamman1997,p.276)

One hardly needs labour the point that the juxtaposition of surrealistic and realistic situations triggered by the affective fallacy which demonstrates the courage and altruism of the mannequin leads inexorably to satirical anti-anthropocentrism in the context of human and socio-political circumstances of the civil war. According to Evelyne Accad, satire figures as a characteristic feature of al-Samman's writing style:

Al-Samman is a dynamic person who has founded her own publishing house and seeks to popularize her liberal ideas through a writing style that is by turns emotional, humorous, and even satiric. This is noteworthy because there are relatively few women writers in any culture who have attempted much humor or satire.'(Accad 1993,p.238)

Arab World English Journal for Translation \& Literary Studies 
Al-Samman's keenness to dismantle and to deconstruct anthropocentrism seems to be inspired by a growing body of critical and theoretical work (sometimes referred to as animal studies) concerned with the question of the animal that is based on the assumption, as previously pointed out, that animals exhibit characteristics that are often said to define the human, such as the use of language, altruism, suffering, mourning and so on. These views inform Matthew Calarco's theory about the emergence of new social movements that are seeking to develop a postliberal, posthumanist approach which advocates the overcoming of anthropocentrism Calarco 2008, 6. In his seminal book Zoographies (2008) Calarco goes so far as to suggest:"simply let the human animal distinction go." (Calarco 2008,p.149)

It is against this background that we should interpret al-Samman's characteristic tendency to create a"bond"(24) between human beings and animals as well as her frequent self-identification with animals, birds, and insects Al-Samman 1997,(81,295). On a particular occasion she writes:

I paced around the house like an animal that's fallen into a deadly trap. As I moaned and groaned, I could hear my voice mingling with the groans of the creatures in the pet-shop. All of us were together in the same trap. As for the pet shop. All of us were together in the same trap.(Al-Samman 1997,p.119)

Interestingly, towards the end of the novel, the narrator is transformed into a small owl.

Al-Samman's exposure of the fallacy of anthropocentrism acquires a socio- political dimension in her cutting irony produced by the juxtaposition of the frequent broadcasting of the state's radio station of national songs celebrating Lebanon as a hymn to might, honor, love and glory and the portrayal of atrocities and inhuman practices of the civil war fighters. Al-Samman dwells at length on highlighting this ironic juxtaposition to the end of accentuating her socio-political critique of the civil war. The juxtaposition is worth quoting at some length:

However, there was no way to avoid listening to our' honourable'radio station, which was something I hadn't done for quite a while. At six-thirty I began listening to a song that went something Like this:' What a beautiful morning! Together with our neighbours, our hearts full of joy, we live a life of ease and bliss. 'The song left me utterly bewildered. How could this' honourable' radio station of ours be playing songs about' a life of ease and bliss' when the only' neighbours' left to us were misery and wretchedness?

Little did I know what other surprises awaited me. I'd awakened at dawn to the roar of explosives ripping through our paralysed city. But the song I heard next said: 'With the dawning of the morning light, work's wheels keep on turning; the fact was that the only things 'turning' any more were the cartridge clips inside artillery pieces! 
At seven-thirty the strains of 'Love Story' wafted over the air, though the only 'love story' taking place in Beirut was between daggers and wounds, as it were...

At a quarter to eight some disc jockey had the audacity to play a song which said: 'Oh my country, oh dance of brooks and streams, oh playground of sparrows, its paths flanked by ears of grain and grapevines of gold... Her highways and byways are paved with stories and tales, her roofs and terraces mirrors...'then the singer repeated the refrain, which said: 'Built renown and honour, lifted on high like the winds... 'It was truly horrifying.( AlSamman 1997,pp.109-110)

The alternation between the tenor of the songs and the official inauthentic narrative produced by the state's radio station, on the one hand, and the narrator's horrific description of the atrocities wreaked on the people by fighters in the quotation, on the other hand, gives the lie to the anthropocentric false claim that the world is conceived as human centered, and therefore endlessly available as a source of human comfort, wealth and well-being as the songs tend to affirm.

Just as al-Samman places her own conceptions of anthropocentrism within the political and historical context of the civil war as part of her socio -political and moral critique of the war, so she uses surrealistic representation of death to maintain her attack against anthropocentrism, questioning and rethinking its basic conceptions. In the changed world of the civil war death, we are told, figures as a character who plays the role of a storyteller, he even has a book of fairy tales for children. All of his stories which carry the title of "Invoice" describe atrocities and horrific tragedies of the civil war. One of the most grotesque and absurd invoices describes how a taxi driver who had managed to save the lives of his seven passengers by diligently passing through several security checkpoints eventually he kills them in cold blood. Another ironic invoice describes how several shepherds have been murdered on the first day of Eid Aladha, thus replacing, as it were, their sheep as sacrificial lambs on the occasion of Eid Aladha ( the Muslims' sacred Festival of Sacifice). Al-Samman's presentation of civil war as an image of a grotesque and nightmarish apocalypse of a changed world culminates in her description of society that has come to be dominated by a veritable death cult to the extent of using the word death in naming things, such as "Death River", "Death Bridge", and "Death Street"(Al-Samman,1975,p.195). Active civil war fighters go so far as to found an 'organization' called "Long Live Death"(196). The death of Maron ( a christian shopkeeper) three times referred to in Nightmare (110) provides further example of society's infatuation with the act of killing in the bizarre grotesque world of the civil war:

The first checkpoint he came to was manned by a fellow named Husnayn, who, when he heard Maron's name killed him on the spot. After he'd died, Maron got up again and continued on his way home. At the second checkpoint he was stopped by a man named 
Joseph. When Joseph discovered that Maron hadn't joined Joseph's team, he killed him twice over. (Al-Samman 1997,p.250)

Obviously, Maron falls victim of his religious and sectarian affiliations, affiliations which play a crucial role in fueling and prolonging the duration of the civil war. Here is how alSamman, employing her artistic power of imagination, highlights very common acts of killing in the name of identity:

One of the bodies shouted: 'I'm the nephew of the Sunni Muslim minister. If you don't let me in, my uncle will relieve you of your job!'

Another cried out: 'And I'm the nephew of the Christian Maronite minister. If you don't let me in, you'll be violating the principle of equal representation among the sects and of allowing corpses to be seated along sectarian lines! Besides that, my uncle will have your head!'

'I'm a Shi'itel!' cried another.

'I'm a Druze,' shouted still another,' and my reincarnated spirit will make certain that none of your offspring survive!'

'I'm an Orthodox Christian!' shouted out another.

Then a fourth chimed in, saying: 'I'm a jew from Wadi Jumayyal - a member of a "persecuted minority". And I'll zap you with a guilt complex if you don't let me in. by the way, I also want a flat next door to the synagogue!'.Al-Samman 1997,200)

Killing in the name of identity in a fictional context in the novel resonates with Amin Maaluf's factual documentation of what he refers to as killer identities (associated with the Lebanese civil war) in his book of that name. In an interview with Maaluf conducted by "Middle East Online" he, in response to a question about his concept of killer identities, points out:

What happened in Lebanon is an example of the message inherent in the book "Killer Identities". Identities become a "killer" element when your affiliation turns into a weapon that you brandish towards other. As I told you, I once lived in a period where people had various identities. Nevertheless, those identities did not prevent them from living together and coexisting within the same districts, cities and universities. Such identities did not keep them from being friends and from discussing matters with honesty and affection. Of course, this is not always the case with identities; there are affiliations that can lead to killings. We saw that in the Lebanese Civil War, in former Yugoslavia, and in Rwanda among many other places around the world. I believe we live in the age of 'killer identities'; an age where allegiances transform into weapons 
brandished by some towards others. Unfortunately, this might the prevailing characteristic over the coming decades.(qtd in Al-Zaidi 2019 ,p.45)

Incomprehensible and grotesque acts of killing and death in Beirut Nightmares look backward to surrealistic presentation of death in al-Samman's second volume of the trilogy Beirut 75 in which al-Samman presents prophetic predications of the civil war atrocities before it broke out in 1976. The novel concludes with a series of nightmares which found their way as the main mode of representation in Beirut Nightmares. In one of the nightmares in Beirut 75 we encounter this surrealistic description: "In the shop, the sales attendant brought me a collection of several human heads that were still dripping with blood and said to me." Pick out the hair that you like the most! One head costs fifty Lebanese pounds" (Al-Samman 1995,107).

Al-Samman's extensive use of surrealism throughout Beirut Nightmares as a means of highlighting the incomprehensible aspects of the civil war is sustained till the very end of ; the novel. Here al-Samman uses surrealism to portray her overwhelming sense of disorientation as a victim of the civil war. Al-Samman, during the two weeks of imprisonment in her apartment, has kept waiting for the arrival of a tank to transport her to safety. Eventually the tank came, but in the surrealistic world of the novel the tank is transformed into a kind of stone boat. The narrator tries to navigate to safety by this grotesque stone boat which is of course immobile; even the compass the narrator is using to find her way to safety does not point to the normal four directions (north, south, east and west), instead it points only to a fifth direction" into the depths" of the abyss which engulfs the whole country and its people.

\section{About the Author:}

Professor Nedal Al - Mousa holds a PhD in English and comparative literature from Essex University (1984), and an MA in comparative literature from the American University in Cairo (1977). His research areas include comparative literature, cultural studies translation and literary criticism. He served as the Dean of the Faculty of Arts at the Hashemite University between 2005 and 2008. At present he teaches at the Arab Open University (AOU) Jordan Branch. He played an active role in launching the MA programme in English literature at AOU. He served as an Assistant Director at the AOU Jordan Branch between 2010 and 2012. At AOU he has developed interest in conducting institutional research.

\section{References}

Accad, E. (1993). 'Arab Women's Special Contribution to Literature.' In J. E. Tucker (ed.) Arab Women's Old Boundaries New Frontiers (pp. 50-72) . Indianapolis: Indiana University Press.pp.50-72.

Al-Samman, G. (1997). Beirut Nightares ( trans.N. N. Roberts, ). London: Quartet Books. 
Al-Samman, G. (1995). Beirut 75. ( tras.N. N. Roberts trans). Fayetteville: The University of Arkansas Press.

1-Samman, G. (1981). Al-Aamal Ghair Kamela: Al-Qabila Tastajwib Al-Qattila ( The Complete Works The Tribe Qustions the Victim) (Beirut: Manshurat Ghada al-Samman).

Amuta, C. (1988).' Literature of the Nigerian Civil War.' In Y. Ogunbiyi (ed.), Perspectives on Nigerian Literature 1700 to the Present Lagos: Guardian Books Nigeria Limited. (pp. 85-93).

Al-Zaidi ,M. (2019). 'Are these Killer Identities.' Alsarq Al-Awsat English. Available at https://eng-archive.aawsat.com/mshari-alzaydi.

Bennett, A., \& Royle, N. (Eds.). (2009). An Introduction to Literature, Criticism and Theory (4 ${ }^{\text {th }}$ ed.). Edinburgh: International Book Distributors.

Calarco, M. 2008. Zoographies: The Question of the Animal from Heidegger to Derrida.New York: Colombia University Press.

Cooke, M. (1996). War's On ther Voices: Women Writers on the Lebanese Civil War. New York: Syracuse University Press.

Faraj, N. (1986). Naguib Mahfouz: Life and Literature ( Cairo alHay'a al-Misriya al Amah Lilal-Kitab).

Fussel, P.(1975). The Great War and Modern Memory. London: Oxford University Press. Walder, D. (1990). Literature in the Modern World. London: Oxford University Press.

Walsh, J. (1982). American War Literature. New York: St Martin's Press. 